\title{
On the Enforcement of Specific Performance in Civil Law Countries
}

\author{
Lando, Henrik; Rose, Caspar
}

Document Version

Final published version

Publication date:

2003

License

CC BY-NC-ND

Citation for published version (APA):

Lando, H., \& Rose, C. (2003). On the Enforcement of Specific Performance in Civil Law Countries.

Link to publication in CBS Research Portal

\footnotetext{
General rights

Copyright and moral rights for the publications made accessible in the public portal are retained by the authors and/or other copyright owners and it is a condition of accessing publications that users recognise and abide by the legal requirements associated with these rights.

\section{Take down policy}

If you believe that this document breaches copyright please contact us (research.lib@cbs.dk) providing details, and we will remove access to the work immediately and investigate your claim.
} 


\section{LEFIC}

Copenhagen Business School

\section{Center for Law, Economics and Financial Institutions at CBS}

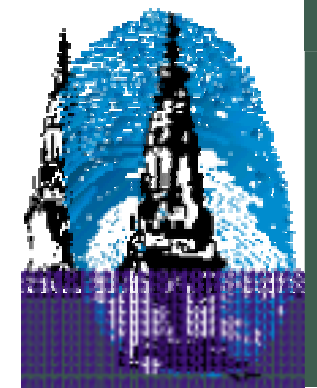

LEFIC WORKING PAPER 2003-14

On the Enforcement of Specific Performance in Civil Law Countries

Henrik Lando

$\&$

Caspar Rose

www.cbs.dk/LEFIC 


\title{
On the Enforcement of Specific Performance in Civil Law Countries ${ }^{1}$
}

\section{By}

\section{Henrik Lando ${ }^{2}$ and Caspar Rose ${ }^{3}$}

\section{June 24, 2004}

\begin{abstract}
:
Proponents of specific performance as a remedy for breach of contract have found support in the alleged use of the remedy in Civil Law countries. However, we provide evidence that specific performance is in fact a rare remedy in Denmark, Germany and France, and under CISG, when performance requires actions to be undertaken, and we relate this to costs of enforcement. We argue that it is administratively costly to run a system of enforcement that renders specific performance attractive to the aggrieved party, and that the Civil Law countries have (like Common Law countries) chosen not to incur these costs of enforcement. This is especially clear in the case of Denmark, where specific performance of actions has been abandoned as a legal remedy.

At the normative level, we argue that enforcement costs provides an additional rationale, over and above the rationales of the theory of efficient breach, for damages and against specific performance as the general remedy.
\end{abstract}

\footnotetext{
${ }^{1}$ We thank, without implicating, Gerrit de Geest, Peter Møgelvang Hansen, Ole Lando, Ejan Mackaay, Thomas Ulen and participants at the 2003 EALE conference in Nancy, and the 2004 ALEA conference at Northwestern University.

${ }^{2}$ Professor of law and economics, Copenhagen Business School
} 


\section{Introduction}

Proponents of specific performance as a remedy for contract breach have found support for their position in the alleged use of specific performance in Civil Law countries. Thus, Ulen states (p. 361):

'... It is worth noting that in the Civil Law countries specific performance is the routine contract remedy...' 4

In a footnote (note 117 ), Ulen then notes:

'Alternatively, it may be argued that specific performance is not, in practice, the routine contract remedy in Civil Law countries. Some scholars note a trend toward convergence in contract remedies in the Civil and Common Law countries. See A. Von Mehren \& J. Gordley, supra note 116 , at 1122-23. There is, however, a dearth of empirical evidence on this point.'

The present article investigates the use of specific performance in three Civil Law countries: Denmark, France and Germany, and under $\mathrm{CISG}^{5}$. In the first part of this article, we find that specific performance has been virtually abandoned ${ }^{6}$ in Denmark, when performance requires some action to be performed, and we find evidence to suggest that it is rarely used in France, Germany and

\footnotetext{
${ }^{3}$ Associate Professor of law and economics, Copenhagen Business School

4 The quote continues: - This is a difficult situation to understand if there is really something to Professor Kronman's contention that confining equitable relief to the case of unique goods corresponds to what freely contracting parties would prefer. Perhaps the tastes of contracting parties in Western Europe are vastly different from those in the Common Law countries, but this is very doubtful...'

${ }^{5}$ UN Convention of the International Sales of Goods

${ }^{6}$ In the sense in which it will be defined here.
} 
in international disputes regulated by the International Sales Convention, CISG.

In the second part, we investigate the underlying reasons for the rare use of specific performance. We argue that for specific performance to be an attractive remedy to the conforming party, a costly system of enforcement must be set in place, which authorities have been reluctant to do. The costs have been regarded as out of proportion to the gain of applying specific performance rather than damages. Our main argument is that as a consequence of less than fully rigorous and effective enforcement, specific performance has (when available) become an unattractive remedy for plaintiffs.

In the third part of this paper, we discuss whether the reluctance to enforce specific performance can be justified.

First, the concept of specific performance needs a precise definition.

On the Definition of Specific Performance

The standard definition of specific performance is that when a party to a contract does not perform his or her obligations, e.g. due to late delivery or the delivery of defective goods, the other party can claim performance by the breaching party ${ }^{7}$ in accordance with the contract ${ }^{8}$. We will define this to mean that if performance does not take place, the State will sanction the breaching party, e.g. through periodic fines, until performance occurs. Note that this definition raises a difficulty well-known from the theory of property

\footnotetext{
7 Thus, the aggrieved party's right to make a cover purchase (buy the good or the service somewhere else) and be compensated for the price difference by the party in breach does not constitute specific performance; in our terminology, it is a right to damages. It is worth noting that the term specific performance is sometimes used for the right to a cover purchase in Civil Law, which may partly account for the impression that specific performance is more widespread in Civil Law than in Common Law, see Beale.

8 Under Common Law, the primary remedy is damages, and specific performance is generally granted for unique goods (and real estate), or at the discretion of the judge.
} 
rules versus damage rules: If the sanction is a one-time payment equal to the loss of the performing party, and paid to this party, specific performance becomes indistinguishable (in its pay-off structure) from damages. To avoid this, we shall define specific performance as a rule that sanctions non-performance through a heavy sanction (and not only through a payment that equals the cost of non-performance). Thus, specific performance will be defined as a property rule and damages as a liability rule, in the sense of Calabresi and Melumad (1997) and Kaplow and Shavell (1996).

As a final matter of terminology, we stress a distinction between duties to act and duties to give ${ }^{9}$, and term breaches of a duty to act an 'action breach', in contrast to the case where the goods already exist and only need to be handed over to the buyer. We do not claim that the duties to give are not enforced, in fact they often are. However, this article concerns duties to act.

A. Empirical part: On the Use of Specific Performance in Civil Law

In this section, we first provide an account of specific performance in Denmark, and then turn to Germany and France, and to contracts adjudicated under CISG. For the reader who is not interested in the detail, a summary can be found in section A6.

\section{A1. The Enforcement of Specific Performance in Denmark}

For commercial contracts, Danish contract law lays down that a party whose contractual rights have been violated may choose between specific performance and damages ${ }^{10}$. However, when it comes to enforcement, the Code of Procedure greatly restricts the

\footnotetext{
${ }^{9}$ although it can in some cases be difficult to know whether a given duty falls in one or the other category.

10 The non-breaching party may make a cover purchase and will often be recompensed under the damage measure.
} 
number of cases for which specific performance will be enforced by the legal system. If the court grants a claim for specific performance, and the defaulting party continues to be in breach, the other party may require the enforcing authority (the bailiff) to enforce the claim. The rules of ultimate enforcement by the bailiff are provided in the Code of Procedure ${ }^{11}$, which stipulates that except in a specified class of cases ${ }^{12}$, the bailiff converts the plaintiff's claim into money damages' (Code of Procedure §533). The bailiff cannot, e.g. by imposing coercive fines, force the defendant to perform certain actions ${ }^{13}$. However, there is one exception to the non-enforcement of specific performance of actions: if the judge has granted specific performance, and the defendant does not comply, the plaintiff may file a private, criminal suit against the defendant (according to $\$ 535$ in the Code of Civil Procedure). Fines or even imprisonment may thereby be imposed on the defendant. However, there seems to have been only one such criminal suit (U 1991.239.SH) in recent times, and in that case the plaintiff did not prevail. The incentive to file a criminal suit seems very limited. It is not without cost to the individual plaintiff (even though if he wins the case some of his observable costs will be paid by the defendant) and he is not awarded the fine. Furthermore, if the plaintiff prevails in a criminal suit, the defendant can only be sanctioned once for not performing ( $\$ 535$, footnote 3 ), and even if the defendant is sanctioned, she does not after the verdict have an incentive to perform. Still, one incentive to file suit does exist: if the breaching party performs, the criminal trial must be stopped $(\S 535,2)$, and so filing suit may induce performance. However, if the defendant thinks she will prevail in the criminal trial, or is simply stubborn,

\footnotetext{
${ }^{11}$ Law no. 469 (3. june 1993).

12 The law states the enforcement in natura as the main rule, and conversion as the exception but this is only a matter of wording.

${ }^{13}$ This is reflected in practice. In an interview carried out by Ulrik Esbjørn, a student at Copenhagen Business School, a Danish enforcing agent said: "As soon as some act needs to be performed by the defendant, we convert".
} 
the suit is likely to have a negative present value to the plaintiff, since the fine is not paid to him and does not by itself induce performance. To conclude, the very questionable incentive to file a criminal law suit and the virtual absence of such suits in practice, together suggest that such suits are not a realistic possibility. Hence, specific performance is not enforced for action breaches.

This leads us to the question whether claims for specific performance are nevertheless filed in court, despite the lack of ultimate enforcement.

A2. The Granting of Specific Performance by Danish Courts

The answer is that parties very rarely seek specific performance, and that courts even more rarely grant it. In a database covering cases reported in the Danish Weekly Law Report (Ugeskrift for Retsvæsen, hereinafter UfR) from 1950 till April 2000, and containing most of the important published cases but no arbitration awards, we have found only a couple of published cases within the last five decades involving a commercial contract where the buyer claimed specific performance in a case concerning the sale of goods ${ }^{14}$, and in no instance was the claim granted by the court. In one case ${ }^{15}$, the court specifically referred to the lack of enforcement according to the above-mentioned $\S 533$ of the Code of Civil Procedure.

However, two exceptions should be mentioned.

As the first exception, courts do establish the right for the buyer to require the seller to cure a defect, and the right for the seller to cure the defect ${ }^{16}$. These may be viewed as rights to specific performance, and this raises the question why courts establish rights that will not be enforced by the bailiff. However, the reason

\footnotetext{
${ }^{14}$ See UfR 1989.1039H.

15 UfR 1976.972V.

${ }^{16}$ In particular, these rights are enforced for consumer contracts.
} 
is that when such a right is established and violated, the violator loses other rights that are in the end enforced as monetary claims, and it is therefore meaningful for the court to establish these rights or their violation, despite the fact that there is no ultimate enforcement in natura. Thus, if the seller does not cure a defect, the buyer obtains the right to a cover purchase as well as certain other rights. Similarly, if the buyer does not allow the seller to cure the defect when that is reasonable, the buyer's right to compensation is limited to the claim that would remain after the seller's cure. Thus, these rights to specific performance are enforced by monetary compensation, and not by periodic fines that are levied by the authorities until performance takes place, at least not when actions need to be performed ${ }^{17}$. Hence, these rights do not fall under the category of specific performance as defined in this article (i.e. as a property rule rather than as a damage rule). The second exception concerns construction contracts for which specific performance has in fact been granted and carried out by the breaching party. However, as a study by Lehmann Nielsen reveals for the case of Denmark, in all such cases both parties to the contract preferred specific performance to a cover transaction (p.178). The following case is an example18: a group of entrepreneurs had agreed to repair a group of houses, which suffered from defects that might prove costly in the future. After signing the contract, the entrepreneurs realized that the costs of repair were out of proportion to the gain. Experts confirmed in court that the expected future loss was very small in comparison to the expense of repair. Still, the Supreme Court voted by 3 to 2 to grant specific performance. This verdict could possibly have been enforced through a cover purchase as seems to be confirmed by the fact that the repairs were eventually carried out by the

\footnotetext{
17 Thus, we suspect that the outcome is not very different from what occurs under Common Law, where e.g. the duty to mitigate losses would tend to produce the same kind of behavior, although not stated as a rule of specific performance.

${ }^{18}$ It is the only such case in UfR (U1989, page 1039).
} 
entrepreneurs ${ }^{19}$; they probably preferred this to a 'cover purchase'20. Thus, the case again illustrates that specific performance is sometimes carried out under the threat of monetary sanctions, in this case the threat of a cover purchase (that leads to a monetary claim against the breaching seller).

Our conclusion is that specific performance of actions is simply not a relevant remedy in the sense in which has been defined here. The parties operate under what is in fact a damage regime, since only damages are ultimately enforced (while the threat of a private, criminal suit is not credible if even available).

A3. The Enforcement of Specific Performance in Germany and France

As in the case of Denmark, in both Germany and France the nonbreaching party can generally choose between specific performance and damages. The question to be raised here is whether specific performance, if granted by the courts, will ultimately be executed in Germany and France.

In the case of Germany, when it comes to the execution of claims of specific performance, the distinction ${ }^{21}$ is made between duties to act and duties to give (see Zweigert \& Kötz 1998, pp. 470). In the former case, a further distinction is made as to whether the act could equally well be performed by someone else (i.e. is 'vertretbar', see $\S 887$ in the Code of Civil Procedure, Zivilprocessordnung, ZPO). If substitute performance is available (at reasonable cost), a claim for specific performance will not be executed, but the plaintiff may conduct a cover purchase, and the bailiff (the Gerichtsvollzieher) will then execute the monetary claim in value equal to the cover purchase. Thus, when substitute performance is

\footnotetext{
19 Our source for this information is the parties' lawyers.

${ }^{20}$ Compare this with the swimming pool cases from France and England mentioned by Beale p. 689 and 691.

${ }^{21}$ It is a distinction which goes back to Roman law, see Dawson (1959).
} 
available, the claim is, if not already at the court-level ${ }^{22}$, ultimately converted to a money claim. However, if substitute performance is not available, the breaching party can be threatened with a fine or imprisonment, if she refuses to deliver ( $\S 888$ in ZPO). This has been a major difference to Danish law, since the change in the Danish Code of Civil Procedure in 1916. There are, however, further exceptions in German law: performance must not depend on the seller's inspiration or special effort ${ }^{23}$ but must rather have a more routine character. Also, $\S 888$ describes some other situations where the penal pressure is also not available, notably in employment contracts ${ }^{24}$.

For the case of France, although the Code Civil provides the right to claim specific performance, this principle is modified in Art. II42, that prohibits any judgment obliging the seller to act in a particular way. The idea behind Art. II42 is that citizens are 'free' and should not be forced into a certain course of action by the State, unless important public interests are at stake. However, according to Zweigert \& Kötz (1998, p. 475), how far this principle is carried in practice is unclear.

Also the French Code Civil makes the distinction between an 'obligation de faire' (to do) and an 'obligation de donner' (to give). For the case of 'faire', French courts administer a special system of fines (astreintes) that are paid from the breaching party to the conforming party, if the breaching party does not perform. However, the enforcement of the system of 'astreintes' is not strict. In the terms of Zweigert \& Kötz (p.475): 'We may sum up by saying that French law generally admits the issuance of judgments for

\footnotetext{
22 The most likely outcome is that the non-breaching party makes a cover purchase and sues for damages in the amount of the cover purchase which is then granted in accordance with the rule of expectations damages.

${ }^{23}$ This is often mentioned but according to Dawson no cases of this nature exist.

${ }^{24}$ We have been unable to find out the extent to which the German bailiffs will actually use coercive fines in such cases but we suppose that they will do so if the plaintiff requires it, since the law is quite clear on this matter.
} 
performance in kind but enforces them in a very grudging manner'.25

A4. On the Granting of Specific Performance in Germany and France

For the case of Germany and France, no databases were available to us. Instead, we rely on the accounts by legal experts, and report a consensus in the comparative literature on contract breach, that damages is by far the dominant form of relief for actions breaches in both Germany and France.

This consensus view was in fact already expressed by Ernst Rabel, who stated in 'Recht des Warenkaufs' (1936) that the difference between Common Law and Civil Law is small in practice (see volume 1, p 375 ff.).

Also, writing in 1959, Dawson (1959), while stressing the difference between enforcement in Germany and France, noted that for the case of Germany (p.530): 'despite formal limitations (on the right to sue for damages, ed.) the damage remedy is in fact resorted to, by the choice of the litigants, in a high percentage of cases, especially in sales of goods and other commercial transactions'.

In present time, the Principles of European Contract Law contains a section called 'practical convergence' (p. 400), where it is plainly stated that: "The basic differences between Common Law and Civil Law are of theoretical rather than practical importance'.

The only view to the contrary that we have been able to find is in 'Rechtsverwirklung durch Zwangsgeld'26, by Oliver Remien (1992) who discusses the German case-material. He writes (our translation) ${ }^{27}$ :

\footnotetext{
${ }^{25}$ Dawson (1959) criticized the ineffectiveness of the use of 'astreintes' and called the whole French system non-sensical due to the lack of effective enforcement, see p. 524-525. However, changes have occurred since Dawson wrote. We are grateful to Gerrit de Geest for pointing these changes out to us. 26 'Enforcement of claims through fines'.

27 'Das Zwangsgeld findet beit unvertretbaren Handlungen ein weites und vielfältiges Anwendungsgebiet”.
} 
'Fines are used as a means of coercion in many areas where substitute performance is not possible'.

Some of the cases that he mentions do not involve (complex) actions to be taken, such as where a company is forced to render its accounts (p. 134, a case from 1933), but others do: One case from 1897 concerns the delivery of electricity to a hotel, and another case from 1985 concerns the reparation of a computer by the deliverer. Still, from the cases mentioned, the impression remains that specific performance is rarely used, especially in commercial transactions, and this is also the conclusion reached by Kötz and Zweigert (p. 484):

'In Germany... where the claim to performance is regarded as the primary legal remedy, it does not in practice have anything like the significance originally attached to it, since whenever the failure to receive the promised performance can be made good by the payment of money, commercial men prefer to claim damages rather than risk wasting time and money on a claim for performance whose execution may not produce satisfactory results'.

The absence of specific performance should not be overstated: As in Common Law, specific performance is sometimes sought, granted and executed also in Germany and France. Thus, in Beale's account of the French and the German systems, one can find cases from both Germany and France where specific performance is indeed applied (see Beale, p. 683-685). However, this seems particularly (but not exclusively) to be the case for construction contracts, where performance can often be induced under the threat of a cover purchase, and for the delivery of already existing goods, that fall outside the scope of this article. 
The CISG (United Nations Convention for the International Sale of Goods) was the first major international sales law accepted by a large number of nations. CISG is now ratified by more than 55 countries around the world, including leading trade nations.

Article 46 (1) provides that the buyer may require performance by the seller of his obligations ${ }^{28}$. However under article 28 , a court is not bound to enter a judgment for specific performance unless the court would do so under its own law in respect of similar contracts of sale. This means that the courts of the Common Law countries such as USA, Canada, and Australia are not bound to grant specific performance. Still, to the extent that specific performance is available in Civil Law countries, we would expect to find some cases of contracts adjudicated under CISG, that involve specific performance.

To see whether such cases exist we obtained date from the private UNILEX database and the following databases available on the internet; http://www.cisg.law.pace.edu/cisg/database.html and www.jura.uni.freiburg.de These databases contain a large collection of cases adjudicated under CISG from all over the world, including both cases decided by national courts and arbitration awards. Almost all the industrialized countries are represented in the data ${ }^{29}$.

We found 200 cases where the question of specific performance vs. damages is present (often in the sense of the rights to cure defects and to have defects cured which are not rights to specific performance as defined here). What we did not find were cases where the buyer requests delivery of goods and the seller denies to deliver (claiming e.g. hardship). Of the 200 cases, only one case mentions a buyer who claimed specific performance in this sense ${ }^{30}$. A Russian enterprise had sold raw aluminum to a group of buyers

CISG gives both the seller and the buyer the right to claim damages instead of specific performance.

${ }^{29}$ An exception is Japan that has not yet ratified the convention.

30 C.f. Zürich Chamber of Commerce Arbitration Award ZHK 273/95 of 31 May 1996.

http://cisgw3.law.pace.edu/cases/960531s1.html 
located in Argentina and Hungary. After the enterprise was privatized in December 1994, the new owners stopped delivery in February 1995, and the case was subsequently submitted to arbitration in Switzerland. The buyer's request for specific performance was denied for reasons to which we shall return. We did not find other attempts to force delivery of goods. It may be because the rule of specific performance is so clear that it does not invite the kind of disagreement over court outcomes that would lead to trials. Or it may be that cases exist that have not been translated into English. These caveats do not allow us to conclude in strong terms, but our observations are at least consistent with the view that, for international sales of goods, the performing party generally prefers to sue for damages rather than to attempt to force performance ${ }^{31}$.

\section{A6. Summary of Empirical Findings}

In short, our main empirical observation is that specific performance is not enforced in Denmark for production contracts; the only final recourse for the plaintiff in case of non-performance is a private, criminal law suit, and since plaintiffs do not have an incentive to file such suits, they are virtually never filed. Thus, specific performance is not enforced as such; when it is granted, as in some construction contracts and in consumer contracts, it is enforced through a threat of monetary sanctions that serve as compensation to the other party (i.e. through damages). In Germany and France, while enforced (although with many exceptions), claims for specific performance are rare. There is a consensus among legal scholars that, in this area, differences between Civil and Common Law are not of practical importance, and it is therefore also not surprising that among the CISG-cases

${ }^{31}$ In several cases, cover purchases are made and reimbursed under a rule of expectation damages. 
available in English on the internet, we could not find a case where the court forced a party to deliver goods.

\section{B. Explanation of the Rare Use of Specific Performance}

It will now be argued that it may be costly to enforce specific performance, especially if the aim is to make it an attractive remedy for the plaintiff.

\section{B1. On the Role of Costly Enforcement}

The system of enforcement has two stages. At the first stage, if the plaintiff has claimed specific performance, the court decides whether specific performance or damages should be the remedy granted. If specific performance is granted, it may not be clear what it entails; it must often be made precise which actions the defendant has agreed to in the contract, and which have not been performed ${ }^{32}$. This may be costly for the court, since it must in some cases write down the exact obligations of the defendant. On the other hand, if damages are granted, the court must establish the amount of damages, which may also be costly, and which is not necessary when specific performance is granted. On balance, however, the costs of writing down the obligations seem higher on average than the cost of assessing damages.

At the second stage, if the defendant does not comply either with the order of specific performance or with the payment of damages, the bailiff enforces the claim. In the case of damages, this is usually relatively straightforward; the assets of the defendant can be seized, if necessary by force. In the case of specific performance, the bailiff can $^{33}$ induce performance by imposing

\footnotetext{
32 This must be settled by the court, and not by the bailiff; potentially difficult issues of interpretation requires court-proceddings.

${ }^{33}$ In systems where specific performance is available.
} 
periodic fines on the defendant, until he or she performs. This may be costly for at least two reasons. First, it may require spending resources on obtaining information about whether performance has in fact occurred. Naturally, this cost must also be incurred when the remedy is damages, but the point is that under a system of damages, this needs to be investigated only once by the judge, while under specific performance, it may have to be investigated both by the judge and by the bailiff, and possibly more than onc if non-performance continues. Multiple non-performances seem a distinct possibility ${ }^{34}$, especially when the relationship between the parties has turned unfriendly (in which case reputation effects may no longer act as a disciplining device) ${ }^{35}$. Second, applying a system of coercive fines to induce performance is administratively costly, in part because administrative law sets procedures for how individuals can be coerced by the State, and these procedures involve $\operatorname{costs}^{36}$.

We would like to emphasize the point that the costs mentioned above become substantial if the aim is to render specific performance a credible threat for the plaintiff. The credibility of the conforming party's threat to claim specific performance is diminished by the breaching party's threat to delay performance or to repeatedly underperform, and the breaching party's threat to delay or mis-perform may well be credible unless enforcmement is strict ${ }^{37}$. Thus, before a court has decreed specific performance and the bailiff has decreed periodic fines, which in combination may take a long time (sometimes even years, but of course speed of process can be bought at a price), the value of performance to the

\footnotetext{
${ }^{34}$ In some cases, constant supervision is required and while it may not be impossible, it is likely to be costly (see Treitel, pp. 1032).

Ulen (1984) argues the opposite, that reputation effects will induce good performance even in a sour relationship; it seems to us that this may perhaps sometimes, but far from always, be the case.

36 From the experience of public law, it is apparent that the process does not always work efficiently.

${ }^{37}$ Recall the quote by Zweigert and Køtz (p.484): 'commercial men prefer to claim damages rather than risk wasting time and money on a claim for performance whose execution may not produce satisfactory results'.
} 
non-breaching party will often have fallen substantially. This cost to the non-breaching party can as mentioned be further exacerbated by multiple non-performances, and these possibilities tend to make specific performance unattractive to the plaintiff. Of course, the system of enforcement could take these possibilities into account by e.g. compensating for delay (but it is often difficult to provide hard evidence for the cost of delay), by penalizing multiple non-performances, and by speeding up the enforcement process. However, such measures are all costly.

In conclusion, specific performance is administratively more costly than damages, especially if it must be an attractive remedy to plaintiffs.

To these administrative costs must of course be added the costs to the breaching party of being coerced into performing potentially very costly actions. In this article, we view specific performance as a rule that, when a contract is breached, establishes a new contract similar to the old in the requirements for performance, but enforced (explicitly) under a threat of periodic fines. Viewing specific performance in this way raises the following question: why is the system of periodic fines not applied in the original contract among the parties? The answer must lie in the fact that such fines are potentially very costly to the breaching party, since they force performance even when it is very costly (and hardship does not apply). As stressed by the theory of efficient breach, the efficiency loss that may hereby be incurred should naturally be viewed as a cost of specific performance ${ }^{38}$. If the parties renegotiate (which they cannot always be counted on to do), there will be the issue of holdup: the conforming party may attract beneficial terms in the renegotiation under the threat of specific performance. Anticiapating this, the seller will overinvest in performance.

If the parties renegotiate, which they cannot always be counted on to do, there will be the issue of hold-up, which will lead to too much effort in ensuring performance. 
Taking these costs to the breaching party in account leads to the following trade-off in the choice of remedy: On one hand, if the system attempts to secure full and timely compliance, it will have to employ a strict system of enforcement. This may involve high administrative costs and will impose costs on the defendant when costs of performance are high. On the other hand, if the system of enforcement is more lax, the plaintiffs threat of claiming specific performance loses credibility, because of the risk of delayed or defective performance.

As will now be recounted, this trade-off was acknowledged when the decision was made to virtually abolish specific performance (of actions) in the Danish Code of Civil Procedure.

B2. Why Was Specific Performance of Actions Abandoned in Denmark?

A law dating back to 1842 originally prescribed that if the breaching party continued not to perform after a court had decreed specific performance, he could be sanctioned to periodic fines or imprisonment. These sanctions were abandoned as a means of coercion in 1916 when the Code of Civil Procedure was established. Since then, specific performance of actions has not been enforced in Denmark.

The main rationale ${ }^{39}$ behind this change was the perceived need to avoid in the final instance incarcerating a person in consequence of his breach of a commercial contractual obligation ${ }^{40}$. It was argued that this would violate a principle of proportionality and thereby be in conflict with fundamental principles of modern jurisprudence. It was also pointed out that heavy enforcement of specific performance

Based on a Parliamentary Report from 1899, see for references the Parliamentary Report (Betænkning) No. 11701989.

${ }^{40}$ see Parliamentary Report (Betænkning) No. 11701989 
involves the risk of hold-up against the breaching party ${ }^{41}$, and that it is administratively expensive. These costs were judged not to be worth the benefit for the plaintiff of having recourse to specific performance ${ }^{42}$.

In 1989 an expert committee investigated the need for reintroducing the enforcement of specific performance (in order to bring the Civil Code into better conformity with the provisions of contract law).

The committee repeated the arguments just mentioned, although it acknowledged that the system of coercive fines can be employed without resorting to imprisonment in the case where fines are not paid. The committee's main argument for not re-introducing specific performance and for not putting into place again a costly system of sanctions, and costly procedures, was the low demand for specific performance among business people. The committee stated it as follows (p.31 in their Report43):

'The fact that there has been no criticism (of the lack of specific performance, ed) and that the need for stricter enforcement in this area has not been expressed, has been decisive for the committee...'.

To sum up the historical development, strict enforcement of specific performance was abandoned in 1916 (if not before), because it was seen as both unnecessarily coercive (compared with its benefit relative to damages) and administratively expensive. It was not reintroduced when up for evaluation, because of the perception that the demand for the remedy was to small to justify the costs of making the remedy available.

\footnotetext{
${ }^{41}$ and that the plaintiff may speculate in which remedy to use: specific performance if prices go up and damages if prices fall (for seller-breach).

Note that the same reasons have been given by Common Law judges for only enforcing specific performance under certain circumstances, see e.g. Beale pp. 710-713, and Treitel pp. 1033-34.

${ }^{43}$ Betænkning nr. 1170.
} 
B2. Explaining the Overall Pattern of Specific Performance

More generally, the presence of enforcement costs seems to be able to explain the overall pattern of enforcement of specific performance. Note e.g. the following features of the systems of enforcement:

1. All systems distinguish between 'duties to give' and 'duties to make'. This seems more attributable to the presence of enforcement costs than to the potential efficiency loss of specific performance, since the efficiency loss may arise both for duties to give and for duties to act, while the enforcement costs are relative small for duties to give compared to the enforcement costs of duties to act.

2. Cover purchases are generally allowed in both Civil and Common Law (and, when a cover purchase is available, specific performance will not be enforced, at least not in Germany). Again, this seems more readily explainable as a way of economizing on enforcement costs than as a way of ensuring efficient production decisions. In terms of efficiency, cover purchases may pose some of the same issues a specific performance when the buyer's valuation of the good is lower than the production cost of the alternative supplier, so the easy access to cover purchases does not seem to be grounded mainly on efficiency concerns. Rather, the main reason that a cover purchase is much more freely granted than specific performance seems to be that a cover purchase is much easier to enforce than specific performance.

3. Employment contracts and contracts requiring the exercise of the seller's inspiration or special effort ${ }^{44}$ are not enforced specifically in Germany (which is in this respect similar to the French system). This seems well explainable in terms of the costs of supervising and monitoring performance of such acts.

${ }^{44}$ This is often mentioned but according to Dawson no cases of this nature exist. 
4. Under CISG, it has been mentioned that the arbitration tribunal denied specific performance in the one case mentioned above in which it was claimed. It argued that it had no legal support, but the reasoning of the tribunal on this point is not clear ${ }^{45}$. What is more interesting in the present context is the further statement made by the tribunal. It stated that even if CISG was applied, the tribunal fails to see how specific performance could be an appropriate remedy for buyers in this case'. The tribunal pointed to the problems associated with the ultimate enforcement of specific performance of contracts in Russia for the next eight or ten years. The tribunal thus pointed to the problem of constant monitoring or supervision of performance, and the high cost of repeatedly forcing performance.

5. Also under Common Law, costs of enforcing claims for specific performance play an important role for when specific relief is granted. According to Treitel's account of English law (p. 1033), the cost of monitoring or supervising performance is one important factor for the rare granting of specific performance, while the 'heavy-handed nature' of specific relief, the 'injustice' of compelling the breaching party to perform at a loss, and the extent to which the the aggrieved party can be compensated through damages also play a role.

C. Normative implications of the existence of enforcement costs

When a remedy is costly to enforce, this will, ceteris paribus, tend to speak against its use. Two arguments may, however, be made to suggest that enforcement costs should be of little consequence.

1. It may be argued that if the sanction for non-performance is very high (potentially including also the costs of enforcement necessary to render specific performance an attractive remedy for the

${ }^{45}$ See reference to the case in footnote above. 
conforming party), the costs of enforcement will not have to be incurred, since the sanction will deter non-consensual breach.

We shall not go into the arguments of the theory of efficient breach, which the argument raises (see e.g. Shavell (2003)), but instead point to what we believe is a (further) weakness of the argument. The idea of very high sanctions for breach of contract underestimates in our view the imperfections of the legal process. Asymmetries of information may lead to error, and the possibility of error provides a reason not to apply too high sanctions. Imagine e.g. that a party in breach claims that it is impossible for him or her to perform the contract, because an indispensable employee has left the firm. If this is unverifiable to a court (is the employee really indispensable?), the court may either trust the firm, thereby rendering specific performance less available to the aggrieved party, or it may impose the very high sanction for non-performance. In the latter case, the costs of enforcement will have to be incurred, which is a waste of resources, and there will be an injustice to the breaching party, if the employee is really indispensable ${ }^{46}$.

Or imagine that it is not clear which of two parties does not perform, but it seems to be one rather than the other; should the harsh penalty then be applied? When considering such possibilities, one appreciates why sanctions for breach cannot be too high, and why coercive fines and imprisonment ${ }^{47}$ was abandoned in Denmark in 1916 with reference to lack of proportionality between harm of breach and sanction for breach. The argument that one can simply impose a very high sanction that will then not have to be applied ignores the real world difficulties of devising an efficient (and just ${ }^{48}$ ) enforcement system. 2. Another argument (see Schwartz (1984)) for letting the plaintiff choose between specific performance and damages is that one can

\footnotetext{
46 If periodic fines are applied, they will presumably have to be stopped at some point

47 it the party has no assets, imprisonment may be necessary for the sanction to deter breach.

${ }^{48}$ Meaning here that large sanctions should not be imposed on the innocent.
} 
simply let the plaintiff carry the costs of enforcement; the plaintif can then internalize the cost of enforcement in his or her choice. However, if the plaintiff is made to bear the cost of enforcement, his or her threat of claiming specific performance may not be credible. The defendant may then e.g. be able to impose costs on the plaintiff by delaying performance until a stage where enforcement costs have been incurred. If one cannot realistically impose very high sanctions on the defendant, and the plaintiff carries the cost of enforcement, it may become unattractive to claim specific performance, and such claims may become to few to make it worthwhile to design the system to be ready to enforce specifically. In conclusion, we believe that enforcement costs (in a broad sense) provide an argument over and above the arguments in the efficient breach literature for advocating damages as the general remedy ${ }^{49}$.

D. Some further implications of the empirical observations

Our observations concerning the actual use of remedies for contract breach have, we believe, two further implications for the theory of contract breach.

First, our observations suggest that the cover purchase is empirically more relevant than specific performance; cover purchases are routinely enforced and sought by plaintiffs in all of the three countries, and also under CISG. Also, cover purchases involve some of the same efficiency issues as specific performance when the seller has made specific investments and can supply the good at lower cost than alternative suppliers. We would therefore argue that a theoretical discussion of the extent to which cover purchases are allowed ${ }^{50}$ seems more practically relevant than a continued discussion concerning specific performance.

\footnotetext{
${ }^{49} \mathrm{We}$ believe that the common law system where specific performance is granted at the discretion of the judge may well be optimal, to the extent that damages cannot be granted more freely to reflect all of the plaintiffs losses.

50 The cover purchase is analysed in Edlin (1997).
} 
Second, in the analysis of contract breach remedies and of renegotiation design, it is important to study not only what the judge will state but also what the bailiff will eventually do. Broadly speaking, enforcement seems to be more difficult in practice than envisaged both in the literature on breach remedies and in the literature on renegotiation design ${ }^{51}$. Enforcement is a mechanism in itself, and the remedy of specific performance is not well defined, unless the mechanism of enforcement is specified.

\section{E. Conclusion}

We have provided evidence for the very limited use of specific performance of actions in Civil law countries. The remedy is available but rarely sought in Germany and France, and has been (virtually) abolished as a remedy for production contracts in Denmark. We argue that part of the explanation lies in the fact that specific performance is administratively costly to enforce in such a way as to prevent delay and multiple non-performances from being a risk to the plaintiff. The countries have chosen not to incur these costs. In our view, they may well have been justified in this choice; the theory of efficient breach provides the basic rationale for damages instead of specific performance as the general remedy, and enforcement costs adds to this rationale.

\section{References}

Aghion, P., M. Dewatripont \& P. Rey.: "Renegotiation design with unveriable information”. 1994. Econometrica 62, pp. 257-282.

Beale, Hugh: "Remedies for Non-Performance", chapter 6, especially pp. 674-716, in IUS Commune Casebooks on the

\footnotetext{
${ }^{51}$ Such as Aghion et. al (1994) or Maskin and Tirole (1999) on incomplete contracting and elaborate mechanisms for renegotiation.
} 
Common Law of Europe, Beale, Hartkamp, Kötz and Tallon, Hart Publishing, 2001.

Calabresi, C. and Melamed D.: "Property Rules, Liability Rules, and Inalienability: One View of the Cathedral", in Law and economics. Volume 1. Theoretical and methodological foundations, 1997, pp. 520-59 edited by Parisi, F. and Posner, R.

Dawson, John P.: "Specific Performance in France and Germany". 1959. Michigan Law Review, vol. 57.

Edlin S. Aaron: "Breach Remedies". 1998. New Palgrave Dictionary of Law and Economics, Macmillan Press, London.

Frost, Kim: "Ret og pligt til afhjælpning", article in Ugeskrift for Retsvæsen, U.2002B.384.

Gomard, Bernhard \& Møller, Jens: “Kommenteret Retsplejelov" 3 bind (Commentary on the Danish Code of Procedure). 1994. Jurist og Økonomforbundets Forlag 5.udg.

Kaplow, L and Shavell, S.: 'Property Rules Versus Liability Rules: An Economic Analysis', 1996, Harvard Law Review, 109, pp. 713790.

Kronman, A.: "Specific performance". 1978. University of Chicago Law Review 45, pp. 351-382.

Lando Ole \& Beale Hugh: "Principles of European Contract Law Parts 1 and 2 - combined and revised". 2000. Kluwer Law International. The Hague. 
Maskin, E. \& Tirole, J.: "Unforeseen Contingencies and Incomplete Contracts”. 1999. Review of Economic Studies 66, pp. 83-114.

Nielsen, Søren Lehmann: "Bygherrens ret til naturalopfyldelse". 1996. Ugeskrift for Retsvæsen, UfR.1996B.176.

Rabel, Ernst: "Recht des Warenkaufs". 1936. Berlin. (Reprint of 1957 at 'Der Auflage von 1957').

Remien, Oliver.: "Rechtsverwirklung durch Zwangsgeld". 1992. Tübingen, Mohr.

Report for (Danish) Parliament (Betænkning) No. 1170 of 1989.

Schwartz, Alan: "The Case for Specific Performance". 1997. Law and economics. Volume 2. Contracts, torts and criminal law, pp. 65-100.

Shavell S.: "Damage measures for breach of contract". 1980. Bell Journal of Economics 11, pp. 466-490.

Shavell S.: "Economic Analysis of Contract Law”, NBER Working Papers: 9696, 2003.

Treitel, G.A.: "he Law of Contract". 1995. London Sweet \& Maxwell $19^{\text {th }}$. ed.

Ulen, T.: "The efficiency of specific performance: toward a unified theory of contract remedies”. 1984. Michigan Law Review 83, pp. 341-403.

Zweigert, Konrad \& Kötz, Hein: "Introduction to Comparative Law". 1998. Claradon Press Oxford 3.ed. 